\title{
The Pools of Ribosomal Proteins and Ribosomal Ribonucleic Acids During Relaxed Control of Escherichia coli A19 (Hfr, rel met rns)
}

\author{
By JOHN SYKES AND EMILIA METCALF \\ Department of Biochemistry, University of Sheffield, Sheffield S10 2TN
}

(Received 11 July 1978)

\begin{abstract}
The soluble fraction extracted from Escherichia coli A19 (Hfr, rel met rns) during early and late times of phenotypic and genotypic induced relaxed control have been examined for the possible accumulation of ribosomal proteins (r-proteins) and rRNA species during this time of unbalanced macromolecular synthesis. Ribosomal proteins and rRNA species were not found to accumulate within the soluble fraction at any time during this period of relaxed control; even after the typical rRNA accumulation had ceased, r-proteins did not accumulate. It is concluded, from these and related observations, that the r-proteins and rRNA species known to be produced during relaxation must immediately associate to form the unusual ribonucleoprotein particles (e.g. 'relaxed particles' and 'chloramphenicol particles') characteristic of periods of relaxed control. Since r-proteins do not accumulate even when net RNA accumulation halts, it appears that some elements of the normal, basic co-ordination between rRNA and r-protein synthesis/stability persist even during relaxed control.
\end{abstract}

\section{INTRODUCTION}

In exponentially growing bacteria over a wide range of normal growth rates the ribosome content fluctuates with the growth rate. In these circumstances the rate of synthesis of ribosomal proteins (r-proteins) is so closely co-ordinated with that of ribosomal RNA (rRNA) that neither accumulates despite wide variations in their rates of synthesis. Consequently the pool of ribosomal proteins is generally found to be low although it increases with growth rate and its absolute concentration is roughly proportional to the square of the growth rate (Gausing, 1974).

Methionine starvation of the relaxed auxotroph of Escherichia coli A19 ( $\mathrm{Hfr}$, rel met rns) and chloramphenicol inhibition of this strain, and of the isogenic stringent strains $\left(\mathrm{rel}^{+}\right)$, apparently break this fine co-ordination by inhibiting protein synthesis and net protein accumulation whilst permitting the continued synthesis and accumulation of RNA. This is the phenomenon of relaxed control or relaxation. Precursor ribosomal RNAs and messenger RNAs for ribosomal proteins are known to accumulate in these circumstances (Dean \& Sykes, 1974; Dennis, 1976). Although there is a profound reduction in general protein synthesis (to 5 to $10 \%$ of the full exponential rate) with increasing chloramphenicol concentration, the ribosomal protein synthesis accounts for an increased proportion of this residual synthesis. However, in these circumstances and unlike the normal pattern, the individual ribosomal proteins are then produced in non-coordinate amounts (Goodman, 1970; Dennis, 1976).

The $\mathrm{rel}^{+}$(stringent) control gene clearly influences the transcription of the r-protein genes and the rRNA genes (Dennis \& Nomura, 1974). The precise means whereby this 
control is exercised is not clear, nor are the means whereby certain apparently unrelated physiological circumstances (e.g. drug inhibition, $\mathrm{Mg}^{2+}$-starvation of auxotrophs, $\mathrm{K}^{+}$ starvation etc.) influence these RNA and protein genes in a manner which mimics the rel (relaxed) mutation. Many of the observations made upon these phenomena suggest that the r-proteins and their availability may regulate the expression of the r-protein genes (e.g. Dennis \& Nomura, 1975a, b) and may stabilize and limit rRNA accumulation (e.g. see Chang \& Irr, 1973).

The experiments in this paper are therefore concerned with the free pools of ribosomal proteins and ribosomal RNA in the soluble fraction of $E$. coli during early and late stages of phenotypic and genotypic relaxation. During this period the normal co-ordination is distorted as noted above and at later stages net RNA accumulation halts. The results show that at early and late stages the ribosomal proteins which are preferentially and noncoordinately synthesized do not accumulate within the soluble fraction. The ribosomal RNA which is synthesized also does not accumulate within the soluble fraction, and after net RNA accumulation halts, r-proteins still do not accumulate. Some of the normal basic co-ordination between r-protein and rRNA synthesis clearly persists during relaxation.

\section{METHODS}

Escherichia coli $\mathrm{A} 19$ (Hfr, rel met rns) was grown in aerated glucose/mineral salts medium plus methionine, and starved of methionine or inhibited with chloramphenicol $\left(50 \mu \mathrm{g} \mathrm{ml}^{-1}\right.$; Parke Davis \& Co., Hounslow, Middx) as described by Sykes $e t a l$. $(1977 a, b)$. In certain of the experiments, the period of starvation or drug inhibition (i.e. 'relaxation') was extended from 2 to $4.5 \mathrm{~h}$. The growth of the cultures was followed by their turbidity at $540 \mathrm{~nm}$, and the protein and total RNA contents of the bacteria were determined by the modified biuret reaction (Stickland, 1951) and by orcinol estimation (Herbert et al., 1971), respectively.

The methods for the bulk isolation of the soluble fraction and the other subcellular fractions from E. coli, using cycles of differential and zonal centrifugation, have also been described (Sykes et al., 1977a,b). Typical rate-zonal density gradient ultracentrifuge absorbance profiles for the soluble fractions studied in the present experiments are shown in Fig. 3. All the peak soluble fraction samples were pooled as indicated in Fig. 3 for the extraction of proteins. The proteins were precipitated by saturation with ammonium sulphate and all the proteins of a ribosomal character were isolated by the method employing acetic acid (Hardy et al., 1969). The proteins which were extracted were subjected to two-dimensional gel electrophoresis as described by Sykes et al. $(1977 a)$.

Electrophoresis of these proteins in one dimension was performed in $7.5 \%(\mathrm{w} / \mathrm{v})$ polyacrylamide gels, $100 \mathrm{~mm}$ long and cast in cylindrical precision bore glass tubes of $7 \mathrm{~mm}$ internal diameter and $120 \mathrm{~mm}$ total length. Spacer gels were not used and the proteins were dissolved in electrophoresis buffer and, with the addition of sucrose, layered directly on to the gels. The total protein load varied between 125 and $1320 \mu \mathrm{g}$ per gel and electrophoresis was carried out at $5{ }^{\circ} \mathrm{C}$ for $6.5 \mathrm{~h}$ at $5 \mathrm{~mA}$ per gel after a preliminary period of $30 \mathrm{~min}$ at $2 \mathrm{~mA}$ per gel. The gels were fixed and stained for $1 \mathrm{~h}$ in $0.25 \%(\mathrm{w} / \mathrm{v})$ amido black $10 \mathrm{~B}$ dissolved in methanol/water/glacial acetic acid $(5: 5: 1$, by vol.). Destaining was by repeated washing in similar methanol/ water/acetic acid mixture. The stained gels were then scanned at $620 \mathrm{~nm}$ in a Unicam SP500 spectrophotometer fitted with a Gilford linear gel transport accessory.

The RNA was extracted from pooled zonal ultracentrifugation fractions representing the 50S, 30S and soluble fraction peaks, then separated electrophoretically and detected in the unstained polyacrylamide gels as described previously (Dean \& Sykes, 1974; Sykes et al., 1977a). In order to improve the resolution of these RNA analyses, the total soluble fraction peak was divided into four equal, pooled sub-fractions prior to the extraction of the total RNA from each (see Fig. 3). The RNA concentration in the final preparations before electrophoresis was estimated from the absorbance at $260 \mathrm{~nm}$ (Kurland, 1960). Certain of the electrophoretic separations of these RNA samples were halted after $2 \mathrm{~h}$ in order to detect any low-molecular-weight RNA species present. Other separations were continued for $5 \mathrm{~h}$ to resolve the rRNA species (see Results). 

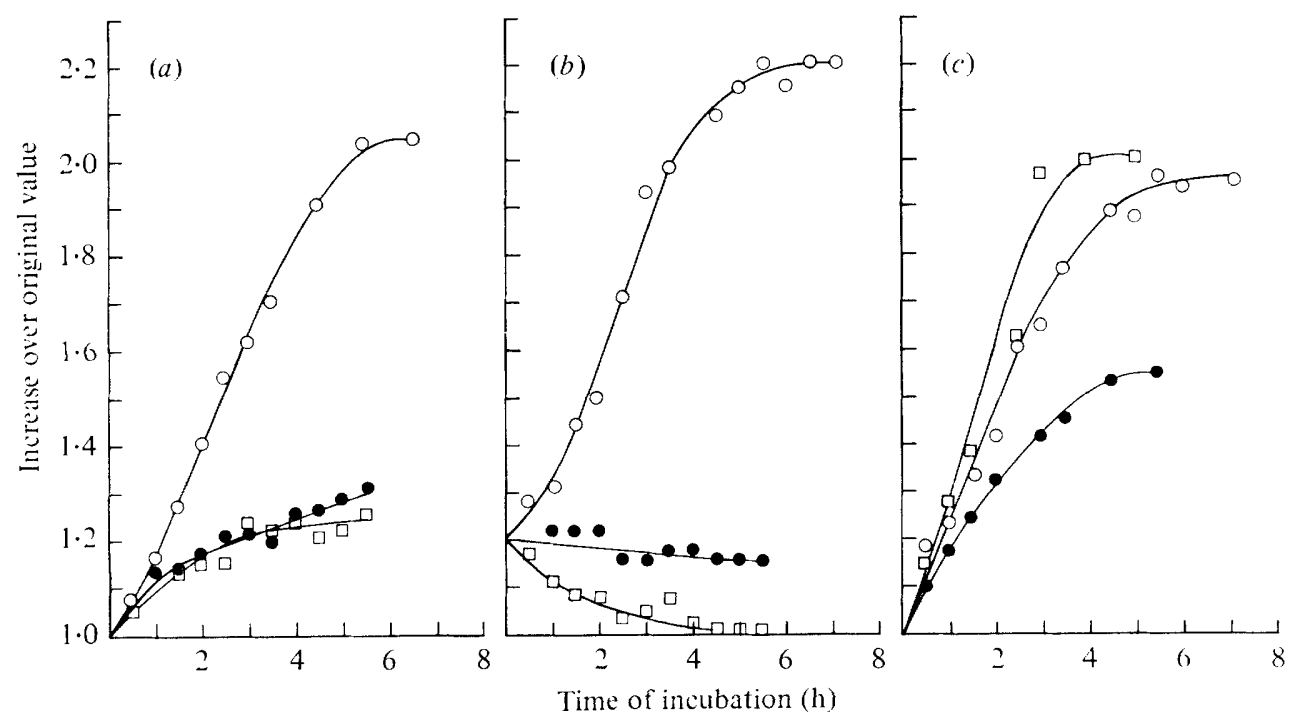

Fig. 1. Increase in turbidity $(a)$, protein $(b)$ and RNA $(c)$ with time of incubation for control $(O)$, methionine-starved (O) and chloramphenicol-inhibited $(\square)$ cultures of E. coli A19 grown as described in Methods.

\section{RESULTS}

Figure 1 shows the changes in RNA, protein and turbidity in control, methionine-starved and chloramphenicol-inhibited cultures of $E$. coli A19 grown under the conditions described in Methods. Growth, as measured by the change in turbidity at $540 \mathrm{~nm}$, was clearly restricted in the methionine-starved and chloramphenicol-inhibited cultures (Fig. 1a). Correspondingly, net protein accumulation within these bacteria was halted immediately (Fig. $1 b$ ) whereas net RNA accumulation continued for approximately $4 \mathrm{~h}$ in all the cultures, and in the chloramphenicol-inhibited cultures it was marginally stimulated (Fig. $1 c$ ). In view of these observations it was decided to examine the pools of rRNA and r-proteins in the soluble fraction of the bacteria after $2 \mathrm{~h}$ incubation, i.e. whilst RNA accumulation was proceeding fully in all cultures, and after $4.5 \mathrm{~h}$ when net RNA accumulation had ceased in all cultures. At these times net protein accumulation was only observed in the control culture and not in the starved or drug-inhibited cultures (Fig. 1b). Compared with the control cultures, RNA and protein synthesis would appear to be uncoordinated in these circumstances.

The analytical ultracentrifuge patterns for crude, cell-free extracts of the bacteria from each culture after $2 \mathrm{~h}$ incubation were the same as previously shown in Figs $1(a)$ and 2(a) in Sykes et al. (1977a) and in Fig. $1(a)$ in Sykes et al. (1977b). During methionine starvation and chloramphenicol inhibition of growth there was an accumulation of the 'relaxed particle' or 'chloramphenicol particle' material which sedimented between the ribosome particle sub-units and the large, slowly sedimenting soluble fraction in these cell-free extracts. Essentially the same analytical ultracentrifuge profiles were obtained for the cell-free extracts after $4.5 \mathrm{~h}$ incubation, although in the extracts from chloramphenicol-inhibited bacteria at this time there was some suggestion of loss or breakdown of the "chloramphenicol particle' material, e.g. compare Fig. 2 in this paper with Fig. 2(a) in Sykes et al. $(1977 a)$.

The slowly sedimenting soluble fraction was isolated from each crude cell-free extract by cycles of differential and zonal ultracentrifugation as described by Sykes et al. (1977a) and the final zonal ultracentrifuge profiles are as shown in Fig. 3. These profiles were the same in extracts made from the cells after 2 or $4.5 \mathrm{~h}$ incubation. The fractions pooled for the sub- 


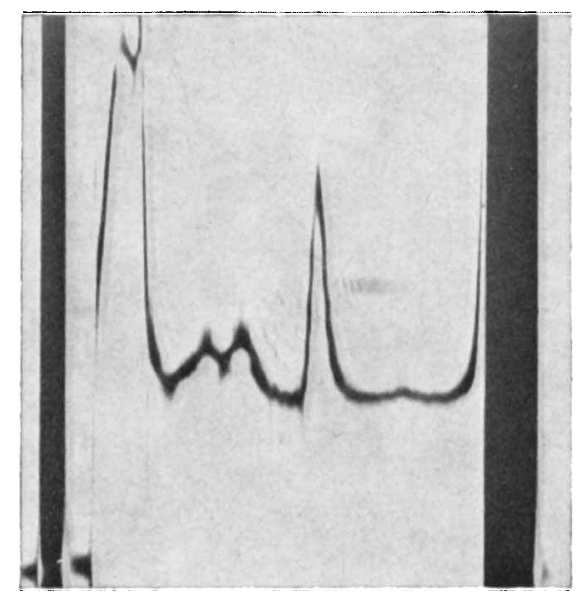

Fig. 2. Analytical ultracentrifuge diagram after $20 \mathrm{~min}$ at speed for a crude cell-free extract $8 \mathrm{mg}$ protein $\mathrm{ml}^{-1}$ ) from $E$. coli $\mathrm{A} 19$ after $4.5 \mathrm{~h}$ inhibition with chloramphenicol. Sedimentation is from left to right. Speed $44770 \mathrm{rev}$. $\mathrm{min}^{-1}$, bar angle $35^{\circ}$, temperature $19 \cdot 3{ }^{\circ} \mathrm{C}$. The 'chloramphenicol particles' sediment between the leading boundary ( $50 \mathrm{~S}$ sub-units) and the large, slowly sedimenting soluble fraction.
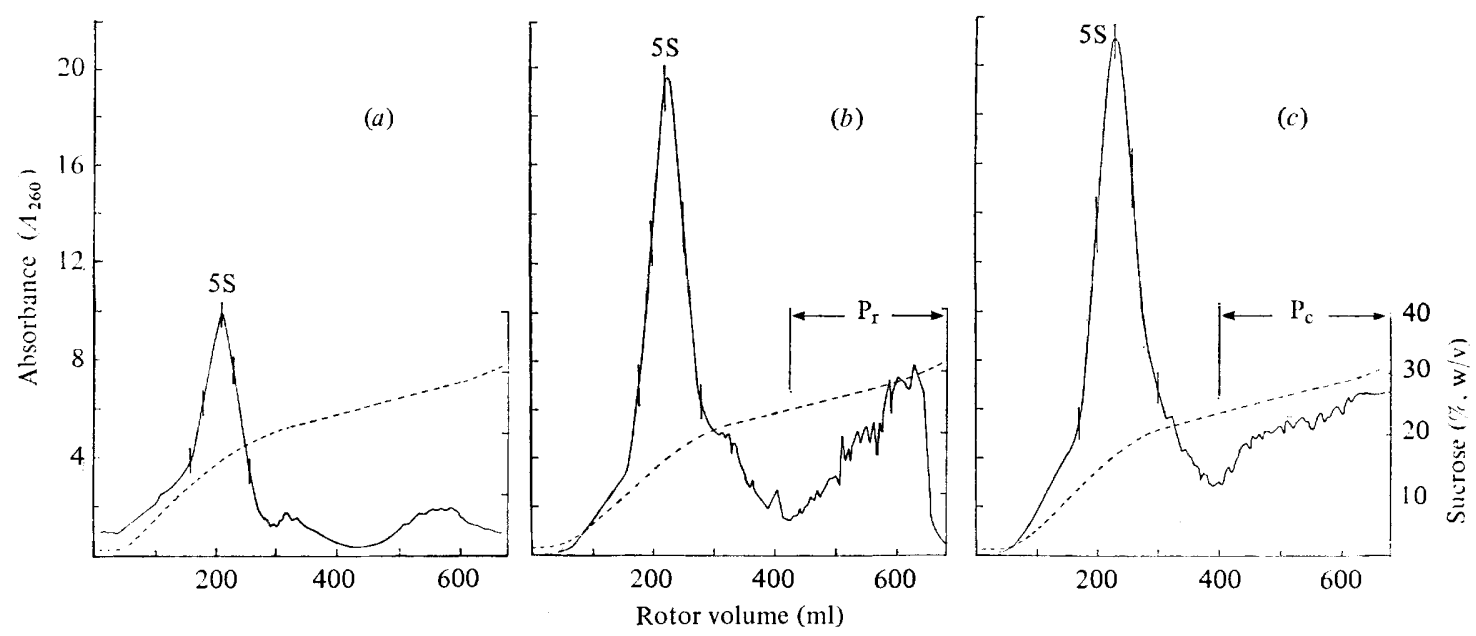

Fig. 3. Rate-zonal ultracentrifuge density gradient absorbance profiles at $260 \mathrm{~nm}$ (continuous line) for the soluble fractions from (a) control cultures after $2 \mathrm{~h}$ incubation, total protein load $200 \mathrm{mg}$; (b) methionine-starved cultures after $4.5 \mathrm{~h}$ incubation, total protein load $330 \mathrm{mg}$; and (c) chloramphenicol-inhibited cultures after $4.5 \mathrm{~h}$ incubation, total protein load $227 \mathrm{mg}$. The samples from each soluble boundary that were pooled for protein or RNA extraction (see Methods) are indicated by the vertical lines. The sedimentation coefficient for the soluble fraction boundary is $5 \mathbf{S}$. Ribosomal sub-units are not present in these supernatant fractions but some 'relaxed particles' $\left(\mathrm{P}_{\mathrm{r}}\right)$ remain in (b) and some 'chloramphenicol particles' $\left(\mathrm{P}_{\mathrm{c}}\right)$ in $(c)$ : see Methods and Sykes et al. $(1977 a, b)$.

Run conditions: Spinco Ti-14 zonal rotor, 36000 rev. $\min ^{-1}$ for $16 \mathrm{~h}$ at $5^{\circ} \mathrm{C}, \Sigma \omega^{2} t=8 \cdot 19 \times 10^{11}$; gradient hyperbolic with radius, 10 to $35 \%$ (w/v) sucrose in $10 \mathrm{~mm}$-Tris/HCl pH 7.8 containing $0.3 \mathrm{~mm}$-magnesium acetate, $30 \mathrm{~mm}-\mathrm{NH}_{4} \mathrm{Cl}$ and $6 \mathrm{~mm}-\beta$-mercaptoethanol (dashed lines indicate the gradients at the end of the runs). 

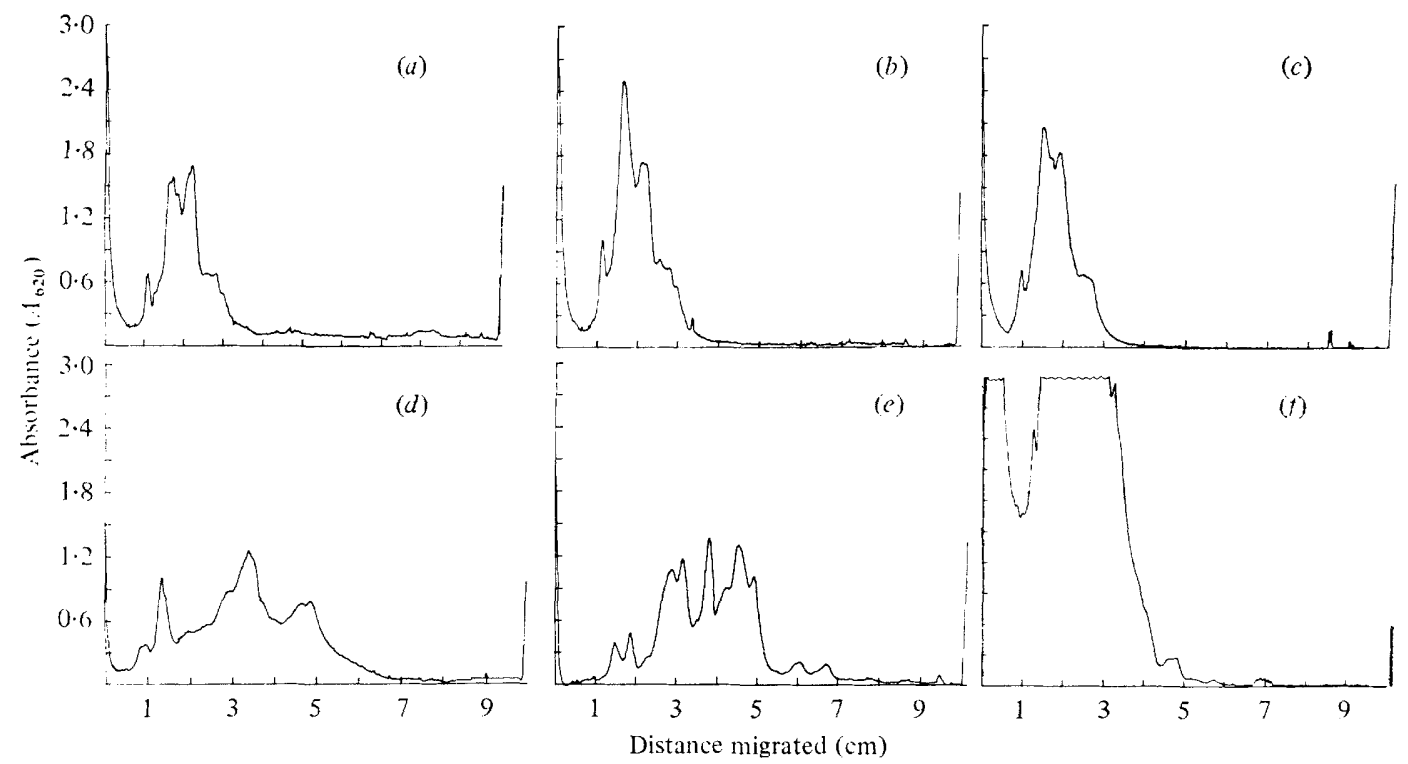

Fig. 4. Absorbance profiles at $620 \mathrm{~nm}$ for stained, one-dimensional polyacrylamide gel separations of proteins extracted from $E$. coli A19: (a) from the soluble fraction of control cells after $2 \mathrm{~h}$ incubation, $133 \mu \mathrm{g}$ protein loaded; (b) from the soluble fraction of methionine-starved cells after $2 \mathrm{~h}$ incubation, $125 \mu \mathrm{g}$ protein loaded; (c) from the soluble fraction of chloramphenicol-inhibited cells after $2 \mathrm{~h}$ incubation, $130 \mu \mathrm{g}$ protein loaded; (d) ribosomal proteins from the $30 \mathrm{~S}$ sub-unit, $162 \mu \mathrm{g}$ loaded; (e) ribosomal proteins from the $50 \mathrm{~S}$ sub-unit, $132 \mu \mathrm{g}$ loaded; $(f)$ proteins from the soluble fraction of chloramphenicol-inhibited cells after $4 \cdot 5 \mathrm{~h}$ incubation, $1320 \mu \mathrm{g}$ loaded.

sequent extraction of the proteins and RNA (see later) to determine the rRNA and r-protein contents of these soluble fractions are also indicated in Fig. 3.

The application of the standard ribosomal protein extraction techniques (see Methods) to the isolated $50 \mathrm{~S}$ or $30 \mathrm{~S}$ ribosomal sub-units gives a recovery of 90 to $100 \%$ of the input protein (Hardy et al., 1969). The application of these same techniques to extract proteins from the pooled soluble peak fractions (see Fig. 3) gave a $70 \%$ recovery of total protein input. This is not unexpected since Sykes et al. $(1977 a, b)$ have shown that the proteins which are extracted in this way from the soluble fraction of normal exponentially growing cultures of $E$. coli A19 are non-ribosomal, i.e. they do not cross-react with antibodies raised against ribosomal proteins and their electrophoretic behaviour is totally dissimilar in pattern to that for ribosomal proteins. This point is confirmed in the present work for the proteins extracted from the pooled, soluble peak fractions from the control (methionine plus) culture (see later and Figs 4, 5 and 6).

The simple one-dimensional gel electrophoretic separation (see Methods) of the proteins extracted in the above manner from the soluble peak fractions from control, methioninestarved ( $2 \mathrm{~h})$ and chloramphenicol-inhibited ( $2 \mathrm{~h})$ E. coli A19 are shown in Fig. $4(a, b, c)$. These electrophoretograms are all similar in terms of the number of components and their relative migration. A comparison of these separations with the corresponding ones for the ribosomal proteins from the $30 \mathrm{~S}$ and $50 \mathrm{~S}$ sub-units from the same organism (Fig. $4 d, e$ ) clearly shows the predominantly non-ribosomal character of the proteins from the soluble fractions. This point is confirmed by the two-dimensional gel electrophoretic patterns in Fig. 5. Figure $5(a, b)$ shows the two-dimensional electrophoretic patterns for the proteins extracted from the soluble fraction of methionine-starved cultures after 2 and $4.5 \mathrm{~h}$ incubation and Fig. 5(c,d) shows the corresponding patterns for bacteria after 2 and $4.5 \mathrm{~h}$ chloramphenicol inhibition. These all confirm the near identity of the protein components seen in the one-dimensional separations and show that this common pattern obtains in the 


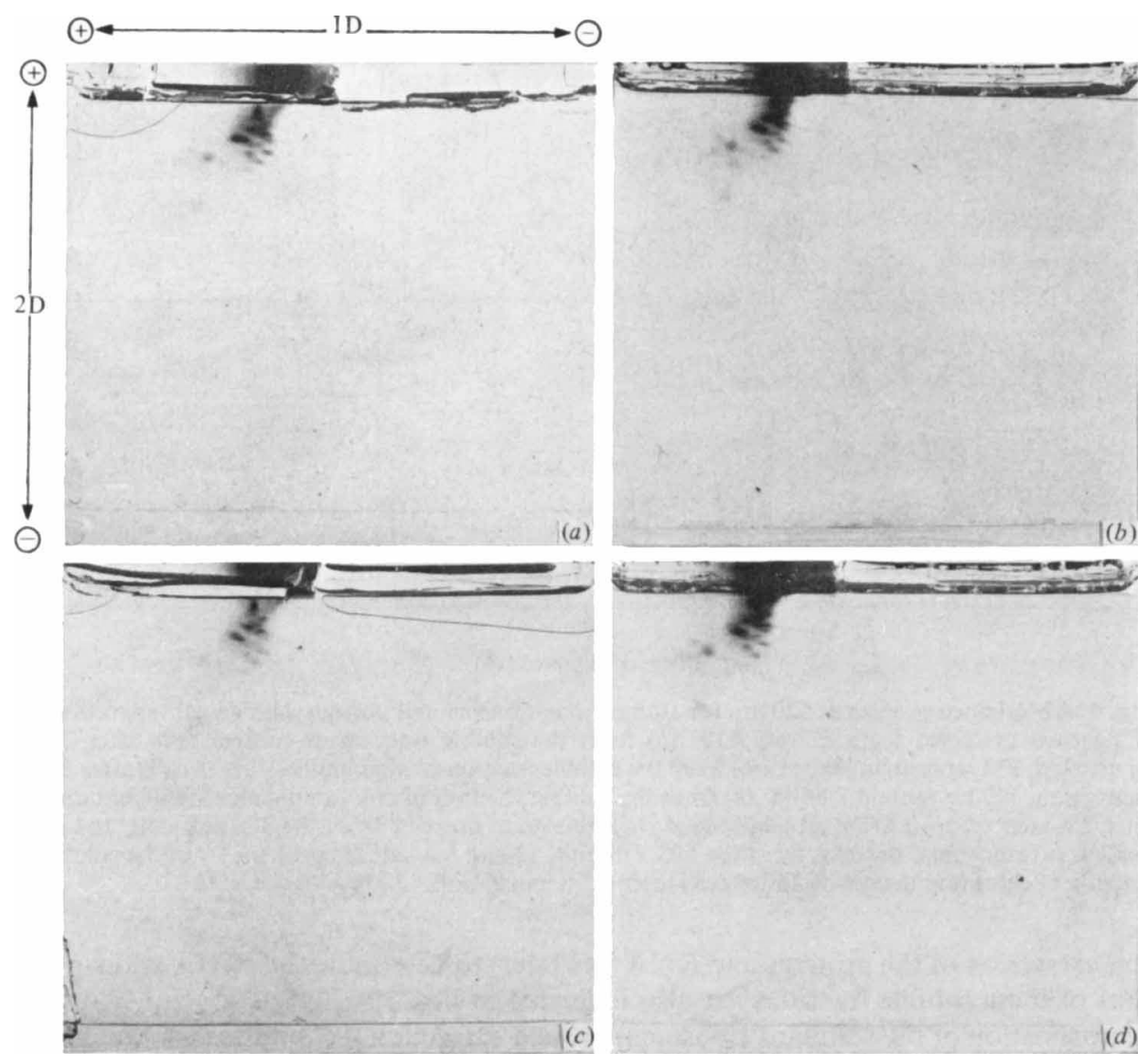

Fig. 5. Stained, two-dimensional electrophoresis patterns for the proteins prepared from the soluble fraction of: (a) $2 \mathrm{~h}$ methionine-starved cultures, $250 \mu \mathrm{g}$ protein loaded; (b) $4.5 \mathrm{~h}$ methionine-starved cultures, $260 \mu \mathrm{g}$ protein loaded; (c) $2 \mathrm{~h}$ chloramphenicol-inhibited cultures, $260 \mu \mathrm{g}$ protein loaded; (d) $4 \cdot 5 \mathrm{~h}$ chloramphenicol-inhibited cultures, $252 \mu \mathrm{g}$ protein loaded.

control culture and at early $(2 \mathrm{~h})$ and late $(4.5 \mathrm{~h})$ times of relaxation in all the soluble fractions. Furthermore, these two-dimensional gel separations confirm that the proteins in the soluble fractions from E. coli A19 in all of these circumstances are non-ribosomal, e.g. compare Fig. 5 in this paper with the corresponding patterns for the normal soluble fraction and $30 \mathrm{~S}$ and $50 \mathrm{~S}$ ribosomal proteins from this organism shown in Fig. 5(a,b,c) in Sykes et al. $(1977 a)$. The proteins extracted from the soluble fractions shown in Fig. 5 in this paper have higher average molecular weights, as shown by their limited migration into the second-dimension gel, and are all acidic proteins. In contrast, ribosomal proteins freely migrate and are resolved in the second-dimension gel and are mainly basic.

In exponential phase bacteria in mineral salt media the estimates of the size of the total ribosomal protein pool as a percentage of the total ribosomal protein vary with the growth rate and the method of analysis. Indirect methods give estimates of the pool size of 2 to $4 \%$ whereas direct estimations give higher values of 2 to $20 \%$. Within this pool, the pools of individual proteins may vary (for surveys, see Gausing, 1974; Sykes et al., 1977b). Recent observations using two-dimensional electrophoresis support the lower range of estimates (Subramanian, 1974; Sykes et al., 1977b) and if a figure of $4 \%$ is assumed this would imply that 1 to $2 \%$ of the total soluble protein fraction of such bacteria would be ribosomal. The selective method of protein extraction used here will relatively enhance these levels (see 

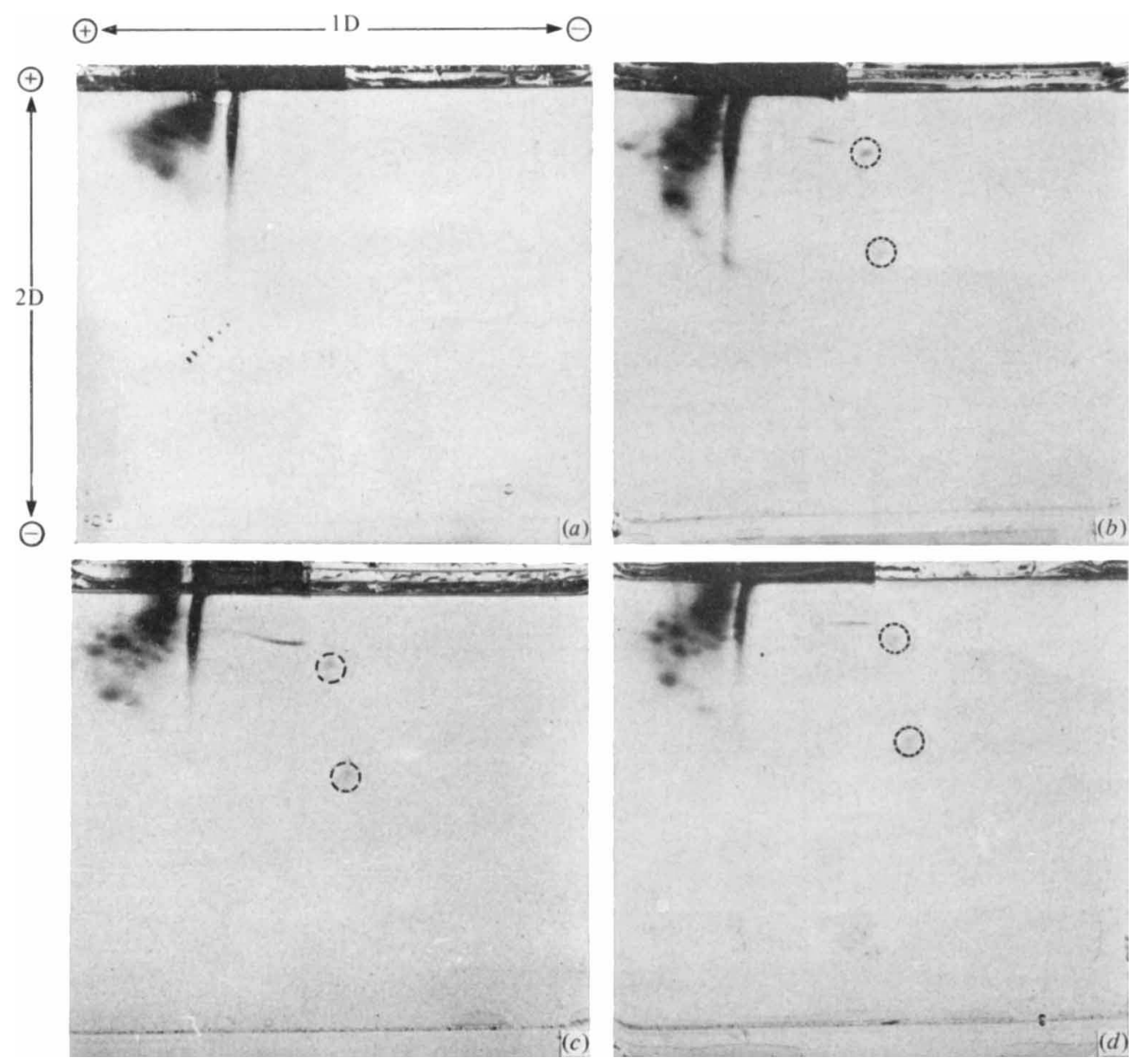

Fig. 6. Síained, two-dimensional electrophoresis patterns for high loadings of the proteins prepared from the soluble fraction of: $(a)$ control, methionine-supplemented cultures, $2 \mathrm{mg}$ protein loaded; (b) $2 \mathrm{~h}$ methionine-starved cultures, $2 \mathrm{mg}$ protein loaded; (c) $4.5 \mathrm{~h}$ chloramphenicol-inhibited cultures, $990 \mu \mathrm{g}$ protein loaded; (d) $4.5 \mathrm{~h}$ methionine-starved cultures, $1 \mathrm{mg}$ protein loaded.

above) and so may the methionine starvation and drug inhibition of growth unless the proteins are immediately utilized. In the one-dimensional gels, the proteins migrate as discrete zones and this, with the gel depth and the further enhancement of sensitivity and detection by staining and scanning, enables $0.1 \mu \mathrm{g}$ protein to be detected. In the small-scale two-dimensional gel technique used here the lower detection limit is $0.2 \mu \mathrm{g}$ per spot (Subramanian, 1974). One-dimensional gels of each of the soluble fraction protein preparations were therefore run using a total protein load in the range 1.2 to $1.3 \mathrm{mg}$ and likewise twodimensional gels were run with loads in the range 1 to $2 \mathrm{mg}$ to ensure the detection of any ribosomal proteins. Visual and spectrophotometric examination of the stained, onedimensional gel separations did not reveal any significant additional components in the regions of the gel occupied by ribosomal proteins (e.g. see Fig. $4 d, e$ ) in any of the soluble fraction preparations from the control cells or at early or late times of relaxation. With these very high loads, although the non-ribosomal proteins occupied their usual position they were overloaded and consequently unresolved. A typical result is shown in Fig. $4(f)$ for the chloramphenicol-inhibited bacteria after $4.5 \mathrm{~h}$ and may be compared with Fig. $4(c, d, e)$. In view of the clear differences in migration of ribosomal and other proteins in the 


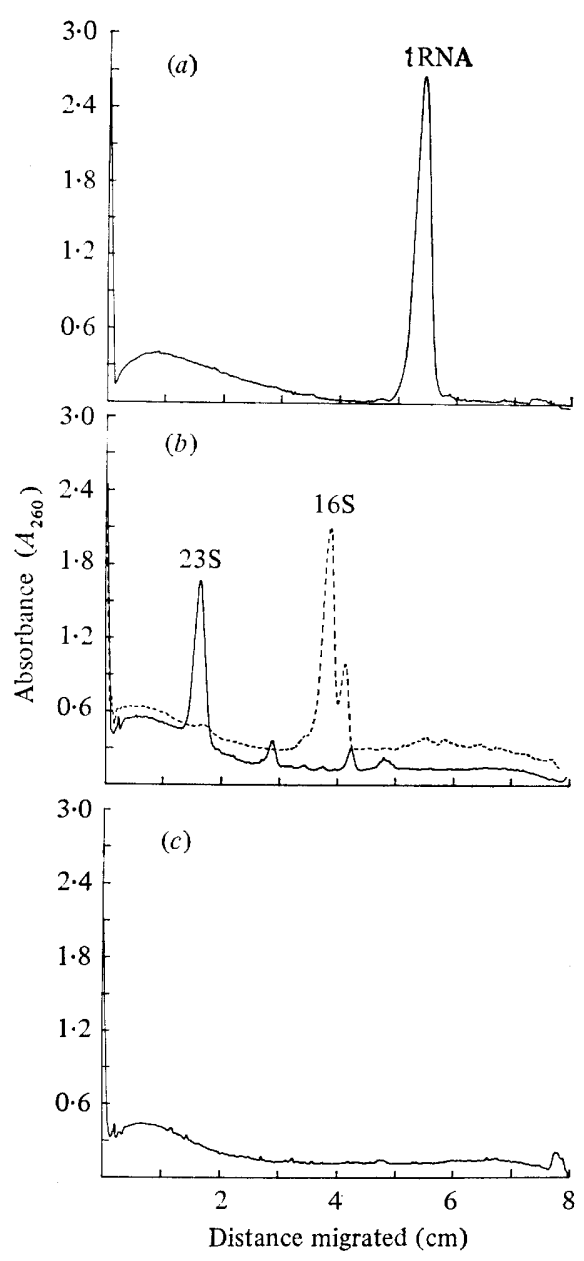

Fig. 7. Typical absorbance profiles at $260 \mathrm{~nm}$ for the gel electrophoretic separations of the total RNA extracted from the soluble and ribosomal fractions of $E$. coli A19.

(a) RNA from the soluble fraction of control cultures at $2 \mathrm{~h}, 19.9 \mu \mathrm{g}$ RNA loaded. Electrophoresis was stopped after $2 \mathrm{~h}$ to show transfer RNA (tRNA). Similar profiles were obtained from methionine-starved and chloramphenicol-inhibited cultures after 2 and $4.5 \mathrm{~h}$ incubation.

(b) Total RNA from 30S $(-\ldots, 18.0 \mu \mathrm{g}$ RNA loaded) and 50S $(-, 23.7 \mu \mathrm{g}$ RNA loaded ribosome sub-units after $5 \mathrm{~h}$ electrophoresis. At this time the 16S rRNA and 23S rRNA species are clearly resolved.

(c) Total RNA from the soluble fraction of control cultures at $2 \mathrm{~h}, 19.9 \mu \mathrm{g}$ RNA loaded. Electrophoresis was stopped after $5 \mathrm{~h}$ (cf. $a$ and $b$ above). Identical profiles were obtained for the corresponding preparations from methionine-starved and chloramphenicol-inhibited cultures after 2 and $4.5 \mathrm{~h}$ incubation.

two-dimensional gels (Sykes et al., 1977a, b), these gels should more clearly reveal any ribosomal proteins which are present. The results for the heavily loaded two-dimensional gels are shown in Fig. 6. In all the soluble fraction preparations (control, methioninestarved and chloramphenicol-inhibited), and at early and late times of relaxation, the level of ribosomal proteins is clearly below $1 \%$ of the total soluble protein pool and does not increase above the control level during extended relaxation. Ribosomal proteins are virtually undetectable although two faint ribosomal protein spots may be discerned at early and late times of relaxation. These are indicated in Fig. $6(b, c, d)$.

The close similarity of the bacterial soluble fraction proteins in all circumstances, and after 2 and $4.5 \mathrm{~h}$ incubation, and the absence of ribosomal proteins at early and late times of 
relaxation when normal co-ordination of RNA and protein synthesis is clearly disturbed (see Fig. 1), shows that ribosomal proteins do not accumulate within the soluble fraction of the bacteria during unusual RNA accumulation and even when this net accumulation halts. It is relevant to note that previous, similar electrophoretic analyses and immunological assays using antibodies to $30 \mathrm{~S}$ and $50 \mathrm{~S}$ proteins also failed to detect ribosomal proteins in the soluble fractions from $E$. coli A19 after starvation for a carbon source for $2 \mathrm{~h}$, i.e. a prolonged period of zero growth (Sykes et al., 1977b). The electrophoretic pattern of the proteins extracted from the soluble fraction of these bacteria was identical to those presented in Fig. 5.

It is known that both precursor (p-) and mature (m-) 16S and 23S rRNA species are amongst the RNA which accumulates during relaxed states and are to be found in the 'relaxed particles' and 'chloramphenicol particles' which arise. These rRNA species are in association with ribosomal proteins (Adesnik \& Levinthal, 1969; Dean \& Sykes, 1974; Sykes et al., 1977 $a, b)$. In view of this and the absence of r-proteins from the soluble fractions noted above, the soluble fractions were examined for the presence of rRNA species. To improve the resolution across each soluble boundary in the zonal ultracentrifuge separations, the total fractions composing the boundary were divided into four equal, pooled fractions as indicated in Fig. 3. The total RNA was extracted from each of these subfractions and examined by gel electrophoresis as described in Methods. After $2 \mathrm{~h}$ electrophoresis in $3 \%$ polyacrylamide gels the transfer RNA species were resolved and were found to be present in all the sub-fractions of all the soluble fractions, i.e. control, methioninestarved and chloramphenicol-inhibited bacteria, at early $(2 \mathrm{~h})$ and late $(4.5 \mathrm{~h})$ periods of relaxation. A typical electrophoretogram is shown in Fig. 7(d). After $5 \mathrm{~h}$ electrophoresis the tRNA species had migrated through the gel and any rRNA species present had migrated into the gel and resolved. This is shown in Fig. 7(b) which includes, for comparison, the ribosomal RNA species derived from $30 \mathrm{~S}$ and $50 \mathrm{~S}$ ribosome sub-units with m16S and $\mathrm{m} 23 \mathrm{~S}$ rRNA species predominating. However, after $5 \mathrm{~h}$ electrophoresis of the RNA from all the sub-fractions of all the soluble fractions at early and late times of relaxation, it was found that precursor/mature rRNA species were absent. A typical profile for these preparations is shown in Fig. 7(c). In view of the sensitivity of these RNA analyses it may be concluded that rRNA species are not present in the soluble fractions of the bacteria during normal growth and at early and late times of relaxed growth. It may also be concluded from this, and the earlier observations of Sykes et al. $(1977 a, b)$, that the precursor and mature rRNA species formed during relaxation are found in the 'relaxed particles' or 'chloramphenicol particles' in association with some r-proteins and not in more slowly sedimenting fractions of the gradient.

\section{DISCUSSION}

Increasing concentrations of chloramphenicol produce a number of unusual differential effects upon protein and RNA synthesis in E. coli. In the first place, increasing the concentration of the drug in a growing culture progressively inhibits total protein synthesis and net accumulation whilst RNA accumulation proceeds normally or is marginally stimulated. Secondly, within this residual total protein synthesis the proportion devoted to ribosomal proteins is increased from the normal uninhibited level of $13 \%$ to approximately $40 \%$ as the drug level is increased. Correspondingly, the proportion of RNA synthesis devoted to messengers for ribosomal proteins is raised from $0.2 \%$ of the total RNA to $0.8 \%$. In addition the relative proportions of the various r-proteins synthesized become sharply altered and the normal pattern of balanced synthesis is replaced at concentrations of chloramphenicol above $20 \mu \mathrm{g} \mathrm{ml}^{-1}$ by a pronounced synthesis of a limited number of r-proteins (Goodman, 1970; Dennis, 1976). Similar, but less detailed observations have been made with amino acid-starved auxotrophs of relaxed strains of $E$. coli (Goodman et al., 1969). In both drug-induced and amino acid-starved relaxation, ribosomal RNA synthesis 
and accumulation continue unabated for 3 to $4 \mathrm{~h}$ (see Fig. 1) and during this period the precursor and mature species of rRNA bind the r-proteins and form the progressively accumulating mass of 'relaxed particles' or 'chloramphenicol particles' (Dean \& Sykes, 1974; Sykes et al., 1977a, b). The observations in this paper show that few, if any, of the ribosomal proteins and rRNA species which are synthesized during these relaxed states accumulate within the soluble fraction of the bacteria at early $(2 \mathrm{~h})$ or late $(4.5 \mathrm{~h})$ phases of relaxation. These observations at the later phase of relaxation are additionally notable since before this time the net RNA accumulation, which is characteristic of relaxation, has ceased. From these observations and the previous observations of Sykes et al. $(1977 a, b)$ it may be concluded that the r-proteins and rRNA species synthesized during relaxation immediately associate to form the 'relaxed particles' and 'chloramphenicol particles'. Furthermore the residual, distorted r-protein synthesis must halt with the RNA accumulation so that the former do not accumulate in the absence of the latter and vice versa. Therefore, although the normal balance between rRNA and r-protein synthesis and the pattern of r-protein synthesis is distorted during relaxation, certain basic elements appear to be retained, viz. the immediate, specific association between ribosomal proteins and rRNA and no accumulation of free r-proteins or free rRNA in the cellular 'pools'. These observations are consistent with the suggestion made by Chang \& Irr (1973) that the maturation and stability of ribosomal RNA depends upon the availability of one or more ribosomal proteins and with the many reports that rRNA precursor forms only exist in vivo in incomplete, ribosome subunit-like particles which lack certain r-proteins. The availability of nascent rRNA and its capacity to specifically bind r-proteins (and vice versa) are clearly interdependent factors in ribosome biogenesis and each may have a bearing upon the expression of the r-protein and rRNA genes. The expression of the r-protein genes may not be regulated simply by the free pool level of r-proteins, as has frequently been suggested (e.g. see Chang \& Irr, 1973; Dennis \& Nomura, 1975a, $b$; Dennis, 1976), but may also depend upon the availability of nascent rRNA.

We are indebted to Mrs P. Clotworthy for technical assistance in many of these experiments.

\section{REFERENCES}

Adesnik, M. \& Levinthal, C. (1969). Synthesis and maturation of ribosomal RNA in Escherichia coli. Journal of Molecular Biology 46, 281-303.

Chang, B. \& IRR, J. (1973). Maturation of ribosomal RNA in stringent and relaxed bacteria. Nature New Biology 243, 35-37.

DeAN, J. R. \& SyKes, J. (1974). The role of ribonuclease II in the maturation of precursor $16 \mathrm{~S}$ ribosomal ribonucleic acid in Escherichia coli. Biochemical Journal 140, 443-450.

DENNIS, P. P. (1976). Effects of chloramphenicol on the transcriptional activities of ribosomal RNA and ribosomal protein genes in Escherichia coli. Journal of Molecular Biology 108, 535-546.

Dennis, P. P. \& Nomura, M. (1974). Stringent control of ribosomal protein gene expression in Escherichia coli. Proceedings of the National Academy of Sciences of the United States of America 71, 3819-3823.

DenNis, P. P. \& Nomura, M. (1975a). Stringent control of the transcriptional activities of ribosomal protein genes in Escherichia coli. Nature, London 255, 460-465.

DenNis, P. P. \& NomURA, M. (1975b). Regulation of the expression of ribosomal protein genes in
Escherichia coli. Journal of Molecular Biology 97 , 61-76.

GAUSING, K. (1974). Ribosomal protein in Escherichia coli : rate of synthesis and pool size at different growth rates. Molecular and General Genetics 129, 61-75.

Goodman, D. (1970). Ribosomal protein synthesis during amino acid starvation and chloramphenicol treatment. Journal of Molecular Biology 51, 491- 499.

Goodman, D., Manor, H. \& Rombauts, W. (1969). Ribosomal protein synthesis during and after amino acid starvation in relaxed and stringent bacteria. Journal of Molecular Biology 40, 247-260.

HaRdy, S. J., Kurland, G. C., Voynow, P. \& MorA, G. (1969). The ribosomal proteins of Escherichia coli: purification of the 30 S proteins. Biochemistry 8, 2897-2905.

Herbert, D., Phipps, P. J. \& Strange, R. E. (1971). Chemical analysis of microbial cells. Methods in Microbiology 5B, 209-344.

KuRLAND, G. C. (1960). Molecular characterisation of ribonucleic acid from Escherichia coli ribosomes. Journal of Molecular Biology 2, 83-91.

STICKLAND, L. H. (1951). The determination of small 
quantities of bacteria by means of the biuret reaction. Journal of General Microbiology. 5, 698-703.

Subramanian, A. R. (1974). Sensitive separation procedure for Escherichia coli ribosomal proteins and the resolution of high molecular weight components. European Journal of Biochemistry 45, 541-546.

Sykes, J., Metcalf, E. \& Pickering, J. D. (1977a).
The nature of the proteins in 'chloramphenicol particles' from Escherichia coli A19 (Hfr rel met rns). Journal of General Microbiology 98, 1-16.

Sykes, J., Metcalf, E. \& Pickering, J. D. (1977 b). The nature of the proteins present in the 'relaxed particles' from methionine-starved Escherichia coli A19 (Hfr rel met rns). Journal of General Microbiology 98, 17-27. 